\title{
Electricity Generation by using a Hybrid System (Photovoltaic and Fuel Cell)
}

\author{
${ }^{1}$ Haider Ahmed Mohmmed, ${ }^{2}$ Othman M. Hussein Anssari and ${ }^{3}$ Layth Mohammed Abd Ali \\ ${ }^{1}$ College of Engineering (COE), University of Kufa, Najaf, Iraq \\ ${ }^{2}$ Information Technology Research and Development Centre (ITRDC), University of Kufa, Najaf, Iraq \\ ${ }^{3}$ Quality Control Laboratory (LQC), University of Kufa, Najaf, Iraq
}

\begin{abstract}
In this study, present a modeling and administrative control for fuel cell with a solar cell as a hybrid power system. The design includes using Photovoltaic (PV) and Ultra-Capacitor (UC) with a Fuel Cell (FC) system is a possible solution to provide sufficient power supplies for residential areas there after reducing the accumulated losses from power transfers to these places. Operations of four modes for the proposed hybrid system are defined for the proposed supervisory control and each model for the PV, FC and UC are developed. The proposed hybrid power system is simulated and analyzed based upon the modeling and the supervisory control algorithm in MATLAB/Simulink environment.
\end{abstract}

Key words: Hybrid system, Photovoltaic (PV), Fuel Cell (FC), Ultra-Capacitor (UC), renewable energy, supervisory control

\section{INTRODUCTION}

Human continues investment in all forms of energy to provide him with the bulk of his energy needs. Where the need for them is enormous as a result of the use of technology (Electrical appliances) to meet daily needs. Energy is produced using fossil fuels in most countries it is an in accessible substance (non-renewable energy). Therefore, alternative sources of energy (renewable energy) have been sought. Non-renewable energy sources are extracted from the Earth (fossil) such as oil, gas, coal, etc., renewable energy sources are on several types including (Valenciaga et al., 2001):

\footnotetext{
Solar energy

Wind energy

Water resources

Tidal energy

Biofuel energy
}

Finding alternatives from the earliest concerns of countries as to the energy of great importance in daily life the following are some differences between renewable and non-renewable energy. Energy generation from non-renewable sources almost by water heating and converting it into steam by burning oil, gas or coal. The process is inefficient as its efficiency varies between $35-80 \%$. Energy generation from renewable sources (Generation of energy from Sun raise, wind or water sources) the process is efficient while the efficiency ratio is between 60-85\% (Uzunoglu and Alam, 2006) (Table 1).
Table 1: Difference between renewable or non-renewable energy

\begin{tabular}{ll}
\hline Non-renewable energy & Renewable energy \\
\hline Their sources are decreasing & Their sources are not decreasing \\
Production costs are high & Production costs are less \\
Working period is & Working period is comparatively \\
comparatively less & more \\
Engineering cadres, specialized & Engineering cadres, specialized \\
technicians are comparatively more & technicians are comparatively less \\
Almost large areas to & Almost large areas to build \\
build stations are needed & stations are not needed \\
Lower efficiency & Higher efficiency \\
Harmful to environment & Friendly to environment \\
\hline
\end{tabular}

\section{MATERIALS AND METHODS}

Solar energy: One of the most important sources of renewable energy is solar energy it is clean and environmentally friendly. Solar energy is the exploitation of the rays and heat that are emitted from interactions in the Sun. The radiation and heat are comes from Sun to the Earth through space and then distributed to different places, concentrated more on areas close to the equator (Kim et al., 2008).

Solar energy works by absorbing solar panels into sunlight-most of the optical spectrum in addition to ultraviolet and infrared radiation and converting it into electrical energy. When photons collide with a solar cell the atoms lose their electrons in a mechanism called photovoltaic effect. Solar panels consist of many cells these cells are made of semi conductors such as silicon it is designed in 2 layers positive and negative layers which is known as electric field.

The solar inverter takes the current from the solar system and turns it into an alternating current. Solar reflectors have captured solar energy industries

Corresponding Author: Haider Ahmed Mohmmed, College of Engineering (COE), University of Kufa, Najaf, Iraq 

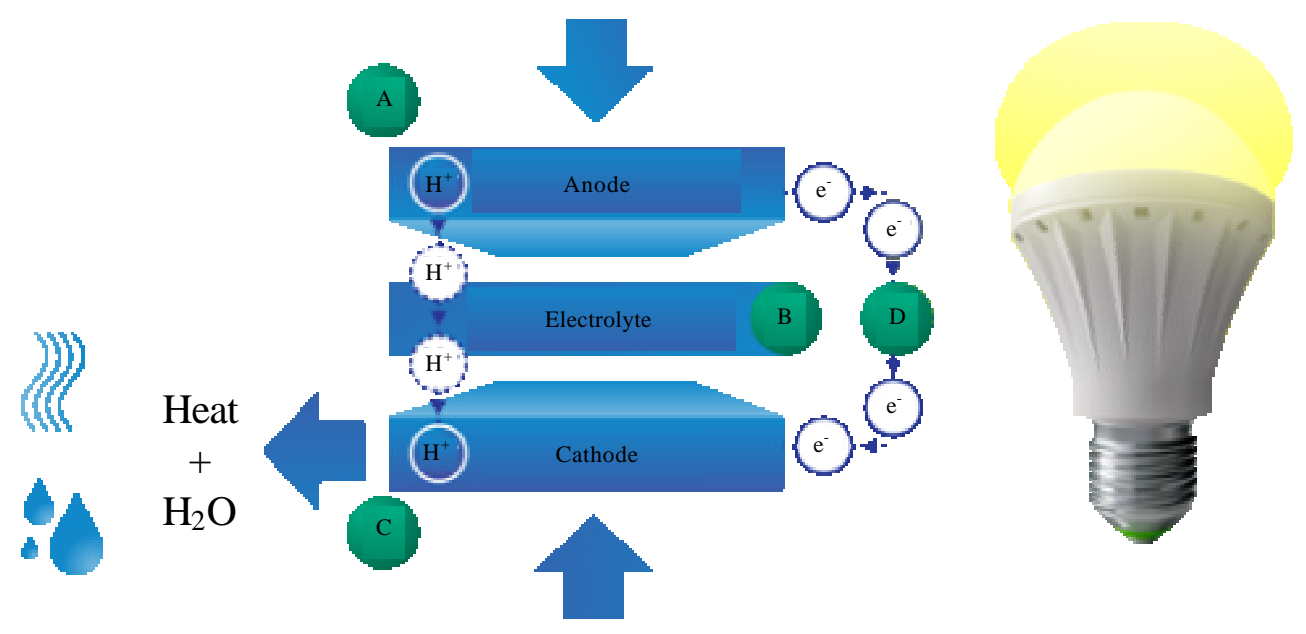

Fig. 1: Fuel cells combine the hydrogen and oxygen elements to produce electricity

(Zhou et al., 2007). When installing solar panels in homes, the Sun shines on these panels and then these panels turn the sunlight into a constant current this current flows into the inverter which in turn converts electricity from DC-AC, electricity can then be used in homes (Rajashekara, 2005).

Solar energy technologies: Solar energy technologies are used to produce electricity, heat, light, hot water and heating and cooling processes. There are a variety of technologies developed such as (Abd and Haider, 2018; Thounthong et al., 2006).

- Photovoltaic power systems

- Solar water heating systems

- Solar electric systems

- Passive solar heating systems and daytime lighting

. Solar systems for heating and cooling

Fuel cell: The reliance on fossil fuels has long been considered dangerous because of persistent and serious environmental problems as well as other disadvantages. The search for alternative sources of energy (especially, alternative to oil) such as the using of solar energy to generate electricity using of tidal energies and sea waves can be used as kinetic energies in electrical energy using fallen water from water falls to generate electricity and replace many alternative energy sources with conventional fuels (Abd and Issa, 2018).

These alternative sources cannot be applied in most countries depending on specific geographical or climatic conditions. In countries where clouds are abundant it is not possible to rely on solar energy and countries that are not near the sea cannot rely on the energy of tides, fuel cells provide a solution and are a good alternative in the future (Andersen et al., 2002). The fuel used in these cells is hydrogen, natural gas or methanol with the usage of oxygen or air, fuel cells are a picture of the process of converting chemical energy stored in hydrocarbons into direct electrical energy (Fig. 1).

Fuel cells combine the hydrogen and oxygen elements to produce electricity which the cell receives from an external source (not a component of the fuel cell itself) which gives these cells importance compared to batteries which distinguishes fuel cells from conventional batteries (Ansari et al., 2018). Components of conventional batteries are the basis of power generation where the chemical reaction of the components of the battery to produce electricity and this process continues until the end of the chemicals reacting, the battery stops until it is re-energized, fuel cells are constantly operating because their fuel, hydrogen and oxygen come from external sources. Fuel cells are flat chips each producing a single voltage. This means that the more chips used more voltage (Hamelin et al., 2001).

Fuel cell work: The fuel cell is a tool to convert chemical energy into electrical energy which through chemical reactions, converts hydrogen and oxygen into water. This process produces electrical energy. The idea of the fuel cells working depends on the transfer of hydrogen atoms from the anode to the oxygen atoms in the cathode and as they pass and interact an electric current is generated and the reaction is the water (Fig. 2). 


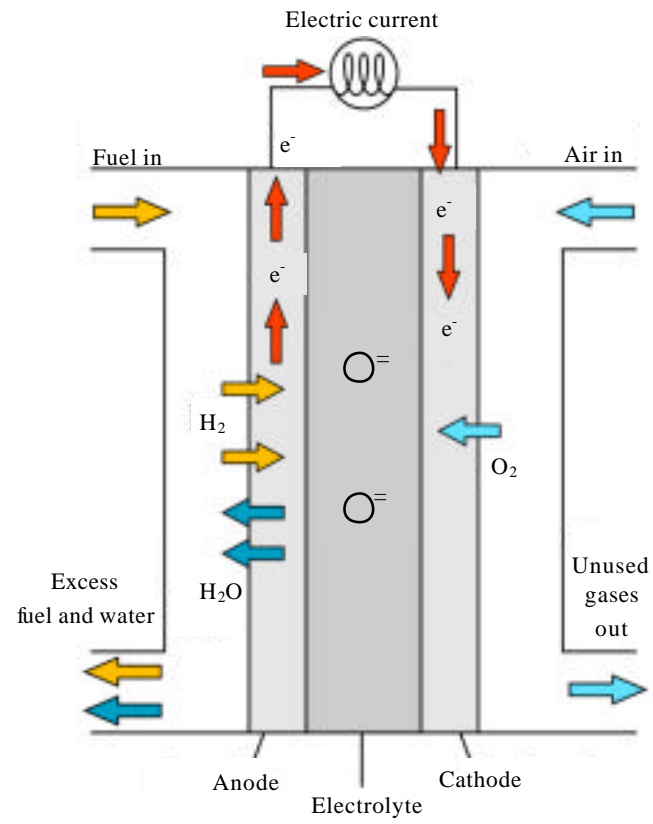

Fig. 2: Fuel cell work

Cathode area: The oxygen is pushed to the cathode and passes through the catalyst which splits the oxygen atom into negative ion (Abd and Issa, 2014).

Anode area: The hydrogen atoms are compressed and pushed to the fuel cell by the anode. When the hydrogen enters the anode it passes through the catalyst. This catalyst splits the hydrogen atom into an ion of positive hydrogen, resulting in 2 electrons. These electrons are the cause of electric power generation and then the circuit completes its path as positive hydrogen ions rush to the negative charge of the oxygen ions to unite and form the water (BPS., 2019). The single cell of fuel cells produces approximately $0.7 \mathrm{~V}$, more than one cell is connected, respectively, to obtain the required voltage value. Applications of fuel cells:

$\begin{array}{ll}\text {. } & \text { Automotive field } \\ \text {. } & \text { Electronics field } \\ \text { Generation of electricity }\end{array}$

\section{RESULTS AND DISCUSSION}

Figure 3 shows which the max loads changing from $8-8.4 \mathrm{~kW}$ with $14 \mathrm{sec}$ as cutting period. In this case, we conclude max. load near to $11 \mathrm{~kW}$ and the photovoltaic system is accessible in $24 \mathrm{~h}$ with Sun rays. The peak interval of the demand conclude $80 \mathrm{sec}$ while that request load $8.5 \mathrm{~kW}$. The peak power of $\mathrm{FC}$ system and

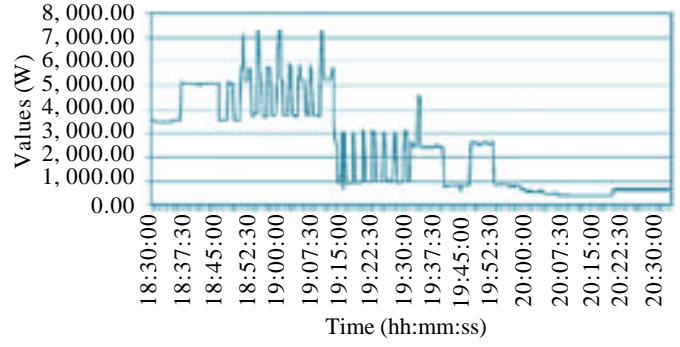

Fig. 3: The $2600-\mathrm{ft} 2$ real power

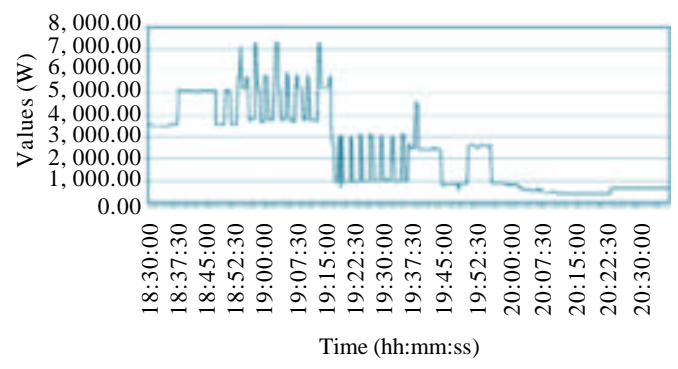

Fig. 4: The current of fuel cell and voltage down variations of load

the photovoltaic system. The energy can stock 0.6 $* 90^{*} 75^{\wedge} 2 / 3600=84.375 \mathrm{Wh}$ that can keep the energy ranking of the additional capacitor $70 \mathrm{Wh}$ if use $\mathrm{FC}$ system with additional capacitor don't need bidirectional converter, 16 additional capacitor (total $2800 / 15=186.67$ ) are required duo to $38 / 2.5 \mathrm{~V}=15.2$. With meet the additional load required $70.7 \mathrm{Wh}$, at min. About 216 additional capacitor in parallel and add more capacitor are anticipated due to 16 additional capacitor in series could stock $0.6^{*} 180^{*} 3662 / 3600=$ $38.88 \mathrm{Wh}$ and 35 additional capacitor can achieving just $65.8 \mathrm{Wh}$ little than max. power required 70 in this case.

The Simulink is achievement an Ballard $6 \mathrm{~kW} \mathrm{FC}$ stack MKS-E composed of 35 cell. evry cell has $233 \mathrm{~cm}$ ' energetic area (Abd and Issa, 2014). The current and voltage, the more important parameters it use for similarity. The load with change between 0 and 150 a imposed on the PGS-105B system which the data are indicated. The load details shown in Fig. 4 which the resistance was change between 0.118-4.16 through the Simulink interval in Fig. 5 shown voltage reduces to $26 \mathrm{~V}$ if just FC worked. the current can be increased because of reduce in voltage over the inner resistor for the FC. Figure 6 shown that administrative control doesn't allow to reduce voltage in a hybrid system of FC below $35 \mathrm{~V}$. Particularly utilizing uni-directional converter will recompense the reducing voltage in $\mathrm{FC}$ and enhances efficiency in the system without utilizing the converter. 


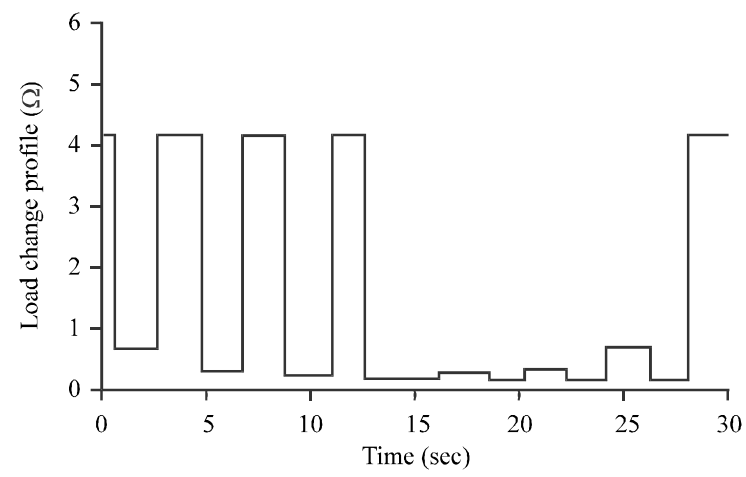

Fig. 5: Variation of load profile
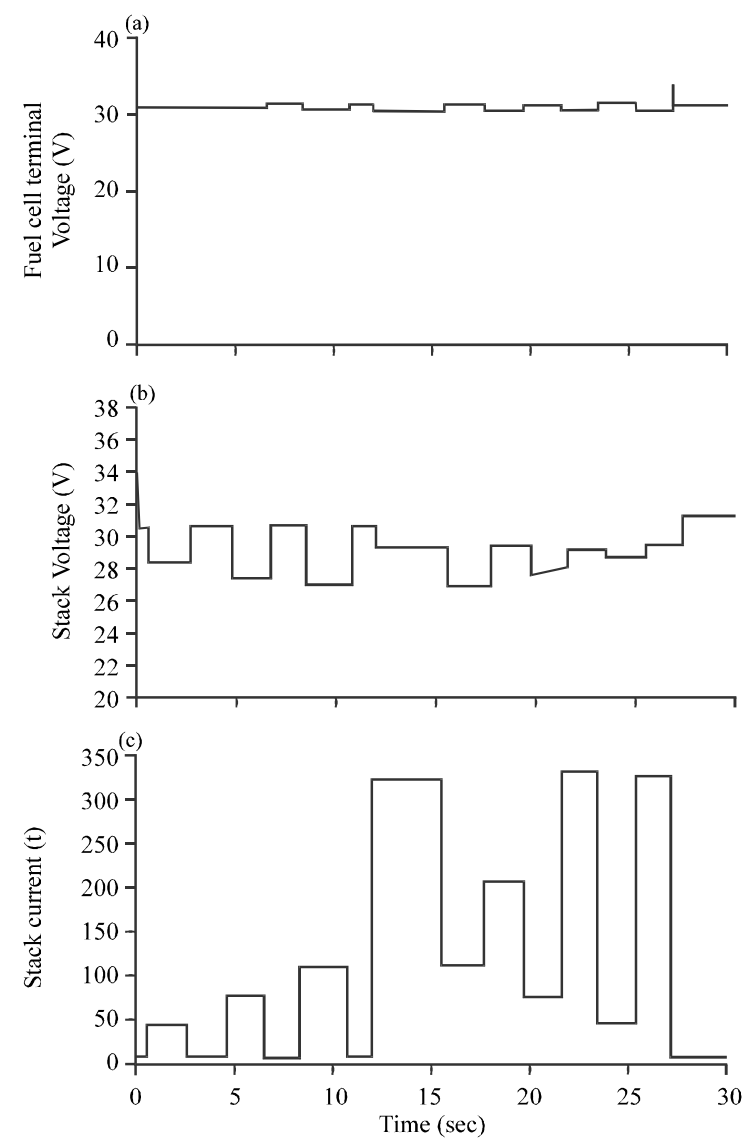

Fig. 6: Current and voltage of fuel cell power system: a) Voltage with the bi-directional converter; b) Voltage without the bidirectional converter and c) Current

Figure 7 and 8 represent the load outlines as the current over $310 \mathrm{~A}$ and the power requirement is $10 \mathrm{~kW}$ because of the reducing voltage.

Figure 9 shows that the ultra-capacitor design can close up residual $2.6 \mathrm{~kW}$ if the required power

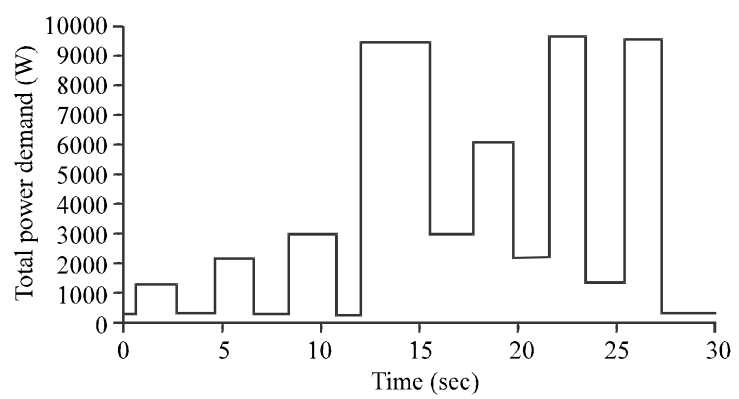

Fig. 7: Sum power required

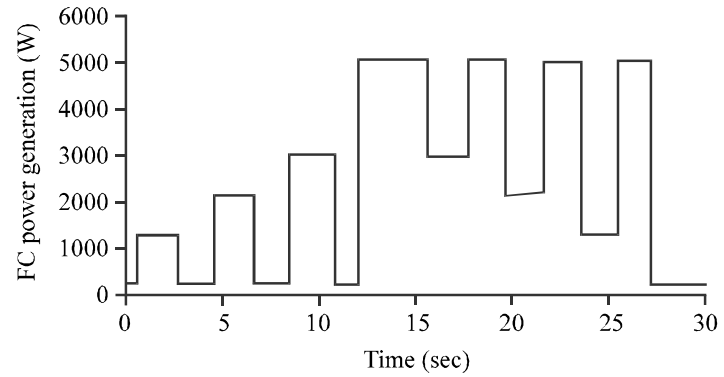

Fig. 8: Power obstetrics of fuel cell

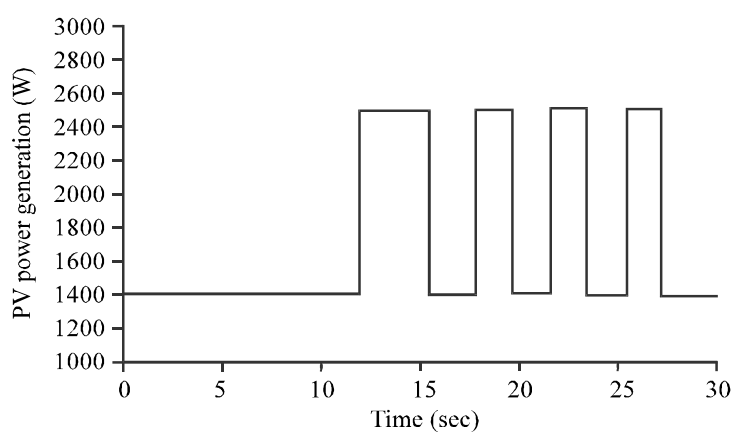

Fig. 9: Photovoltaic power obstetrics

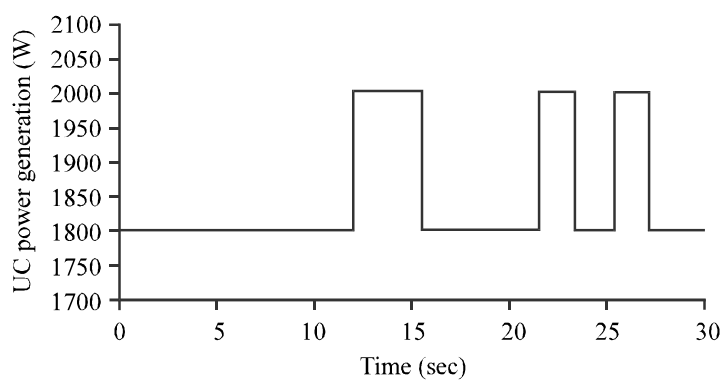

Fig. 10: Ultra-capacitor power obstetrics

ambit $7.8-10 \mathrm{~kW}$ whenever the utmost load power is $9.6 \mathrm{~kW}$. Figure 10 shows the upmost value $2.1 \mathrm{~kW}$ of ultra-capacitor design sufficient to equipped the required power. Figure 11 shows the voltage of ultra-capacitor. 


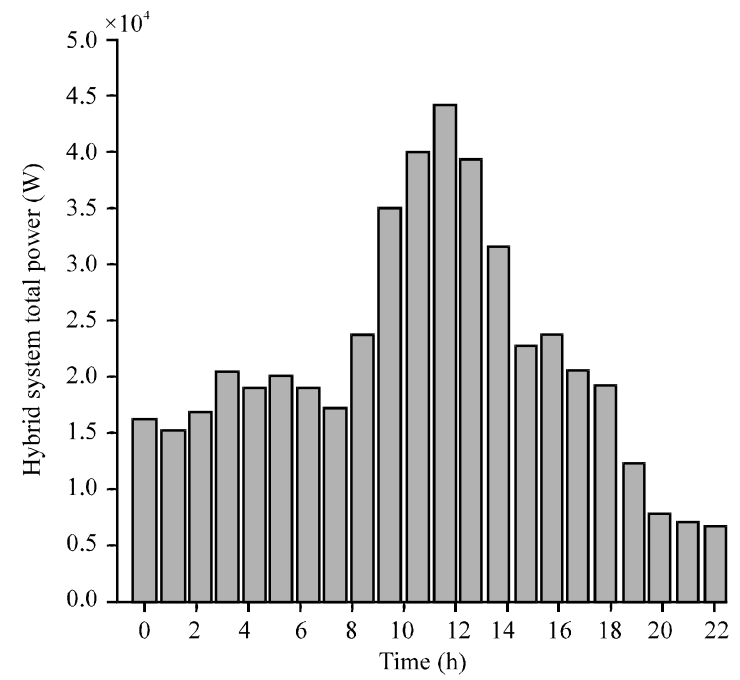

Fig. 11: The voltage of ultra-capacitor

\section{CONCLUSION}

A modeling and supervisory control for a proposed hybrid power system are presented in this study which includes from a FC system, PV system and an ultra-capacitor for stand-alone stationary power applications. During MATLAB/Simulink simulation and results comparison, shows that the proposed hybrid system with the supervisory control improves the dynamic response of the fuel cell system as well as significantly compensate the voltage drop of the FC system due to the load changes reducing the ultra-capacitor size of the system. The proposed supervisory control strategy of the PEM fuel cell system, the PV system and the UC system together, paves a way to supply safe electricity for independent residential areas by alternative energy.

\section{ACKNOWLEDGEMENT}

I would like to take this opportunity to express my profound gratitude and deep regard to my DR Layth Mohammad Abd Ali, for exemplary guidance, valuable feedback and constant encouragement throughout the duration of the project. His valuable suggestions were of immense help throughout my project work. His perceptive criticism kept me working to make this project in a much better way. Working under DR Layth Mohammad Abd Ali was an extremely knowledgeable experience for me.

\section{REFERENCES}

Abd, A.L.M. and A.R. Haider, 2018. Hybrid power generation using solar and wind energy. Young Sci., 7: $19-26$.
Abd, A.M.L. and K.A. Issa, 2014. [Development of smart grid elements for optimizing regional network modes (In Russian)]. Young Sci., 8: 117-120.

Abd, A.M.L. and K.A. Issa, 2018. Using tidal energy as a clean energy source to generate electricity. Young Sci., 11: 62-69.

Andersen, C.A., M.O. Christensen and A.R. Korsgaard, 2002. Design and control of fuel cell system for transport application. Master Thesis, Aalborg University, Aalborg, Denmark..

Ansari, O.M., K.A. Mohmed and M.A.L. Ali, 2018. Design and Simulation a hybrid generation system through wind turbine and solar energy with a heat engine. Young Sci., 38: 11-24.

BPS., 2019. Ballard closes strategic collaboration with Weichai Power. Ballard Power System Inc., Burnaby, Canada. http://www.ballard.com/

Hamelin, J., K. Agbossou, A. Laperriere, F. Laurencelle and T.K. Bose, 2001. Dynamic behavior of a PEM fuel cell stack for stationary applications. Intl. J. Hyd. Energy, 26: 625-629.

Kim, S.K., J.H. Jeon, C.H. Cho, J.B. Ahn and S.H. Kwon, 2008. Dynamic modeling and control of a grid-connected hybrid generation system with versatile power transfer. IEEE Trans. Ind. Electron., 55: 1677-1688.

Rajashekara, K., 2005. Hybrid fuel-cell strategies for clean power generation. IEEE Trans. Industry Applicat., 41: 682-689.

Thounthong, P., S. Rael and B. Davat, 2006. Control strategy of fuel cell/supercapacitors hybrid power sources for electric vehicle. J. Power Sour., 158: 806-814.

Uzunoglu, M. and M.S. Alam, 2006. Dynamic modeling, design and simulation of a combined PEM fuel cell and ultracapacitor system for stand-alone residential applications. IEEE. Trans. Energy Convers., 21: 767-775.

Valenciaga, F., P.F. Puleston and P.E. Battaiotto, 2001. Power control of a photovoltaic array in a hybrid electric generation system using sliding mode techniques. IEEE. Proc. Control Theory Appl., 148: 448-455.

Zhou, T., B. Francois, M.E.H. Lebbal and S. Lecoeuche, 2007. Modeling and control design of hydrogen production process by using a causal ordering graph for wind energy conversion system. Proceedings of the IEEE International Symposium on Industrial Electronics (ISIE 2007), June 4-7, 2007, IEEE, Vigo, Spain, ISBN:978-1 -4244-0754-5, pp: 3192-3197. 